Saba H Al-Zubaidi

BDS, MSc (Assist Lect)

\section{The Skeletal and Soft Tissue Facial Profile in Adolescent and Adult}

\author{
Dept of Pedod, orthod, and Prev Dentistry \\ College of Dentistry, University of Mosul
}

\begin{abstract}
Aims: To evaluate the norms for several cephalometric soft tissue measurements and to investigate differences in the mean values of these measurement between two age groups (11-14 and 18-25) and between two gender. Materials and Methods: The adolescent sample consists from 30 subjects ( 15 for each gender) with age range from $11-14$ years. The adult sample consists from 30 subjects ( 15 for each gender) with age range 18-25 years. The two groups satisfying the criteria of balance facial profile, class I molar relation ship and normal over bite-over jet relation ship. Ten skeletal and soft tissue measurements were obtained from tracing lateral cephalometric radiograph. The data was analyzed using descriptive statistic and student $t-$ test. Results: During adolescence, no significant differences were found between males and females. During adulthood, the males having higher values for all measurements (except nasolabial and mentolabial angles) but statistically not significant. From adolescent to adult males, the angles of facial convexity, Z- angle in addition to lower lip length and nasal depth are significantly different with the adult male having the higher value. For females, the lower lip length and nasal depth significantly higher in the adult period. Conclusions: The adult males having relatively straighter facial profile. In addition, $\mathrm{Z}$ - angle also greater in the adult males than during adolescence. For both genders, the nasal depth and the vertical height of lower lip were significantly greater in adults.
\end{abstract}

Key words: Soft tissue profile, nasolabial angle, mentolabial angle, nasal depth.

Al-Zubaidi SH. The Skeletal and Soft Tissue Facial Profile in Adolescent and Adult. Al-Rafidain Dent J. 2009; 9(1): 149-155.

Received: $25 / 2 / 2008 \quad$ Sent to Referees: $25 / 2 / 2008$

Accepted for Publication: 22/4/2008

\section{INTRODUCTION}

The knowledge of growth related changes is essential in planning orthodontic treatment. It is important to understand and anticipate the amount and relative rate of growth in different parts of the face ${ }^{(1)}$, therefore, orthodontists are interested in defining the changes in the various component of the craniofacial structures, including patient's soft tissue profile ${ }^{(2,3)}$.

Major orthodontic treatment goal is to improve facial esthetic, and the resulting soft tissue profile is one measure of esthetic success ${ }^{(4-6)}$.

There have been numerous soft tissue analysis of the face ${ }^{(7,8)}$, the changes in the soft tissue resulting from growth have been examined from across-sectional (9), semi-longitudinal (10), and longitudinal perspective ${ }^{(11)}$. Most of these studies agree that a trend for sexual dimorphism is evident regarding the growth of the facial soft tissue. In general, the boys tend to demonstrate increase overall growth when compared with the girls and tend to grow for longer period of time ${ }^{(12)}$.

Nose height and prominence increase with age with an average annual increase of $2 \mathrm{~mm}$ between 5 and 10 years ${ }^{(13)}$, the nose continues to grow in downward and foreword direction during adulthood ${ }^{(14)}$.

Nanda et al., ${ }^{(12)}$ reported that growth of the upper lip is completed by 15 years of age in both gender and the average in- 
crease in the upper and lower lips height in males was more than two times that of females. Nanda et al., ${ }^{(12)}$ reported a total increase of soft tissue chin thickness of about $2.7 \mathrm{~mm}$ in males and $2 \mathrm{~mm}$ in females between 7 and 18 years. A similar trend of larger increase in soft tissue chin thickness in males has been reported by Saglam and Gazilerli ${ }^{(15)}$.

The specific objectives of this investigation were to define the norms for several integument variables and to statistically evaluate difference in the mean values of these measurement between two age groups adolescent and adult samples.

\section{MATERIALS AND METHODS}

Two groups of untreated subjects were selected. One of them is the adolescent subjects who were selected from some primary and intermediate schools in the center of Mosul City. The sample consisted of 30 subjects (15 for each gender) with age range from 11-14 years. While the other group is the adult subjects who were selected from those attending the College of Dentistry. The adult sample consisted of 30 subjects with age range from 18-25 years. The two groups satisfied the criteria of balanced facial profile, class I molar relation ship, competent lips and normal over bite-over jet relation ship. The data used in this study were derived from lateral cephalograms obtained with the subject's head positioned in a ce- phalostat and oriented parallel to the Frankfort horizontal plane, the lips in closed position. The radiographs were traced. The skeletal landmarks were determined as described by Thurow ${ }^{(16)}$. The soft tissue landmarks were determined according to the definitions of Chaconas and Bartroff ${ }^{(17)}$.

The angular measurements made are depicted in Figure (1) and included: Angle of skeletal convexity $(\mathrm{N}-\mathrm{A}-\mathrm{Pog})^{(18)}$, angle of soft tissue facial convexity excluding the nose $\left(\mathrm{N}^{\prime}-\mathrm{Sn}-\mathrm{Pog}^{\prime}\right){ }^{(18)}$, angle of total facial convexity (N'-Pr-Pog') ${ }^{(18)}$, soft tissue facial plane angle (N'-Pog' to Frankfort horizontal (FH) plane) ${ }^{(19)}$, nasolabial angle (between the tangent to columela of nose and Sn-Ls) ${ }^{(20)}$, mentolabial angle (between $\mathrm{Li}-\mathrm{B}^{\prime}$ and the tangent to the chin) ${ }^{(21)}$, Z-angle (Pog'-most protrusive lip to Frankfort horizontal plane) ${ }^{(21)}$.

All sagittal and vertical linear dimensions were measured perpendicular and parallel to Frankfort horizontal (FH) plane respectively. The linear variables determined were measured by Zylinski et al., (21) and included: Upper lip length (Sn-St), lower lip length (St-Me'), and nasal depth $\left(\mathrm{Pr}-\mathrm{N}^{\prime}\right)$.

The data were analyzed using descriptive statistics including mean, standard deviation. Student's t- test was used to examine the difference between males and females within the same age group and between the two age groups at $p \leq 0.05$. 


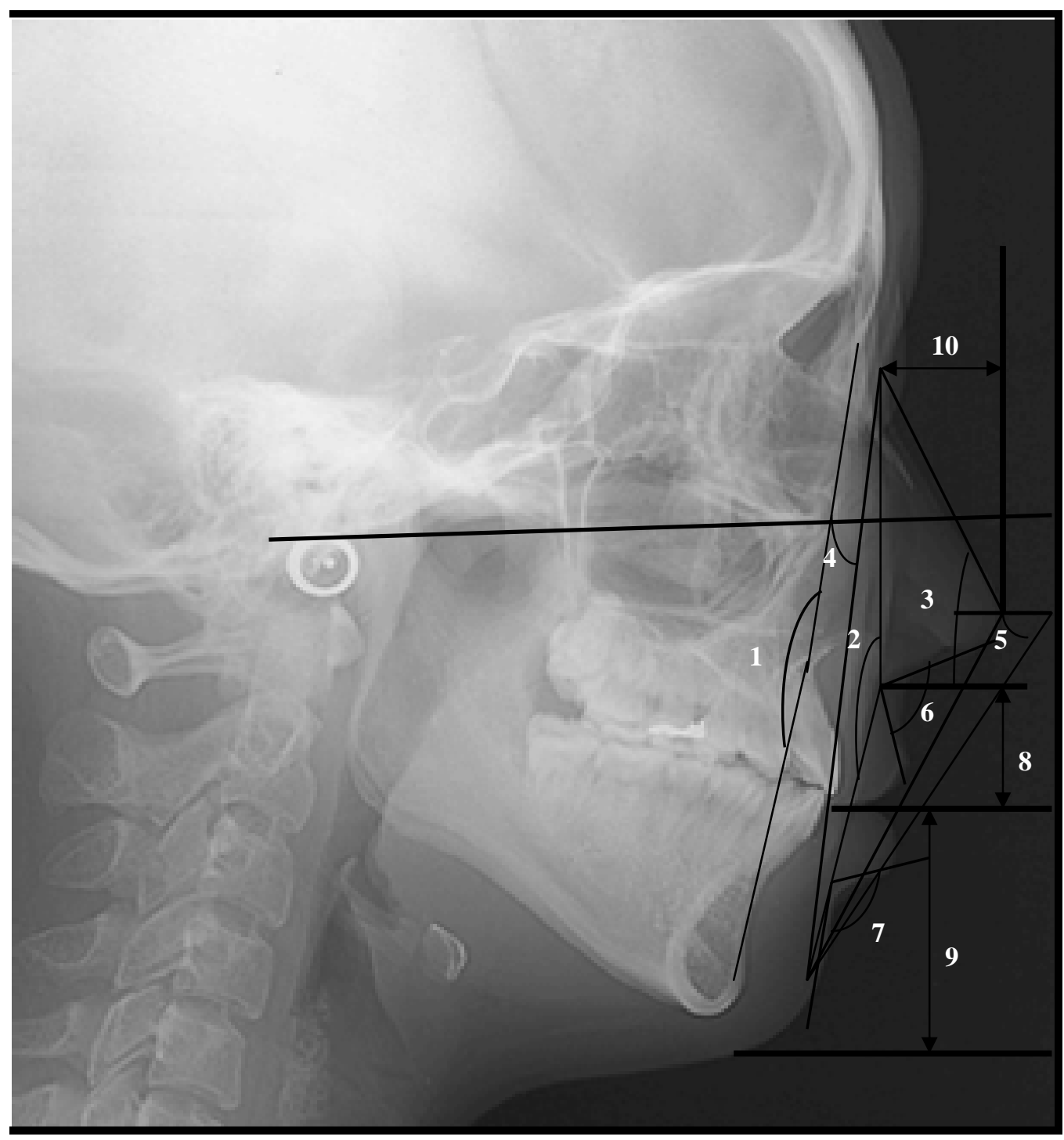

Figure (1): skeletal and soft tissue measurements: 1. N-A-Pog angle, 2. N'-Sn-Pog' angle, 3. N'-Pr-Pog' angle, 4. N'-Pog' to FH angle, 5. Z-angle, 6. nasolabial angle, 7. mentolabial angle, 8. upper lip length, 9. lower lip length, 10. nasal depth.

\section{RESULTS}

The descriptive and student $\mathrm{t}-$ test analysis of the soft tissue profile for the different age groups are presented in Tables $(1,2,3$ and 4$)$.

1. Comparison between males and females during adolescence

Although the Females having higher values for (N-A-Pog) angle, (N'-Sn-Pog') angle, mentolabial angle, $\mathrm{Z}$ - angle and all linear measurements but with no significance.

Males showed higher mean values for (N'-Pr-Pog') angle, (N'-Pog' to FH) angle and nasolabial angle with no significance as shown in Table (1).

2. Comparison between males and females during adulthood

Males having higher mean values for (N-A-Pog) angle, (N'-Sn-Pog') angle, (N'-Pr-Pog') angle, (N'-Pog' to FH) angle, $\mathrm{Z}$ - angle, upper lip length, nasal depth. These values were statistically not significant. While lower lip length was significantly higher in males than in females.

Nasolabial and mentolabial angles were higher in females and statistically not significant as demonstrated in Table (2). 
Table (1): mean, standard deviation, and $\mathrm{t}-$ value for one skeletal and nine soft tissue variables of adolescent males and females.

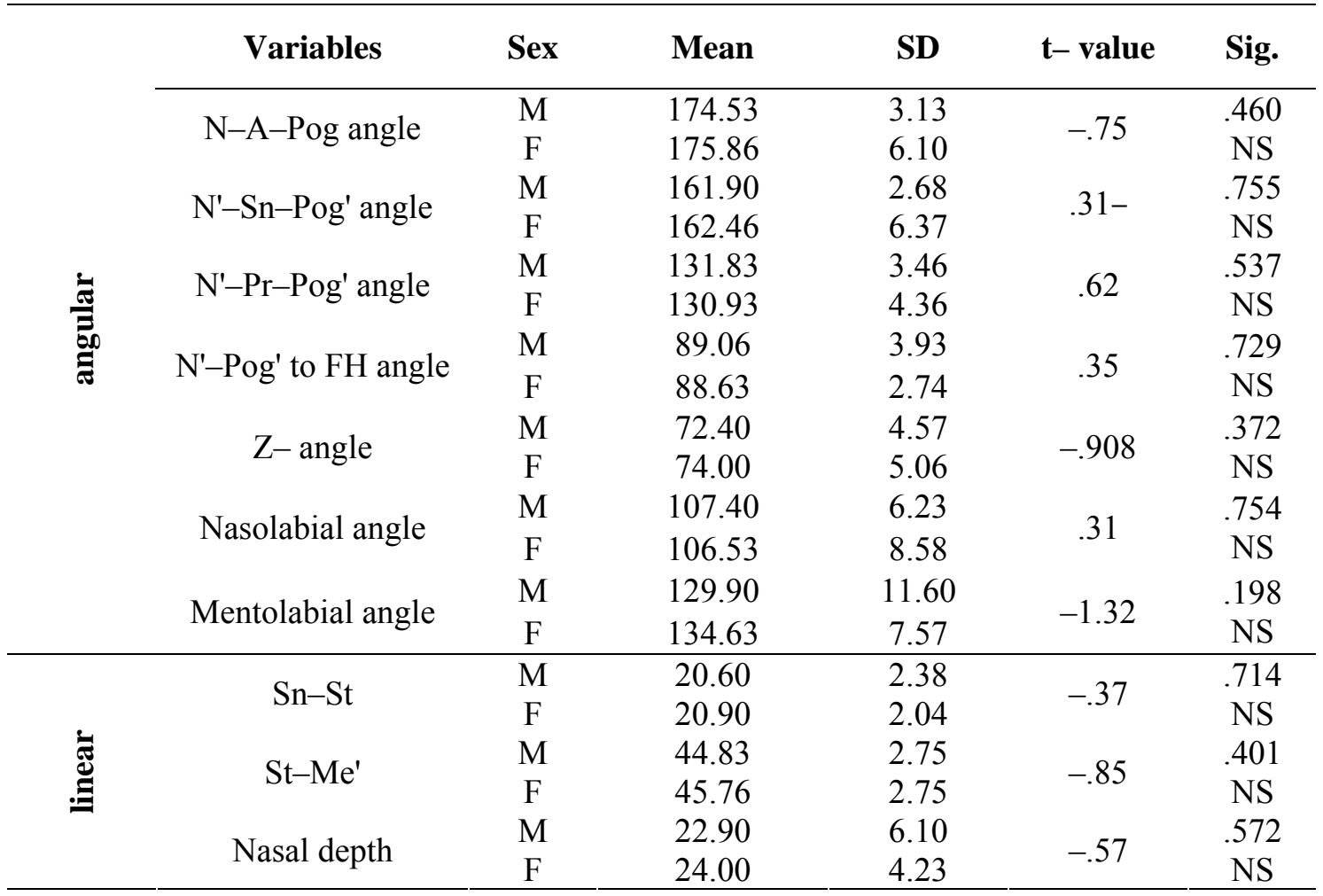

Angular variables are measured in degree, linear variables are measured in mm. SD: standard deviation. Sig: significance, NS: not significant at $p \leq 0.05$.

Table (2): Mean, standard deviation, and $\mathrm{t}-$ value for one skeletal and nine soft tissue variables of adult males and females.

\begin{tabular}{|c|c|c|c|c|c|c|}
\hline & Variables & Sex & Mean & SD & t-value & Sig. \\
\hline \multirow{14}{*}{ 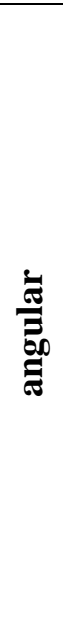 } & \multirow{2}{*}{$\mathrm{N}-\mathrm{A}-\mathrm{Pog}$ angle } & $\mathrm{M}$ & 178.70 & 5.33 & \multirow{2}{*}{2.01} & \multirow[t]{2}{*}{.054} \\
\hline & & $\mathrm{F}$ & 175.13 & 4.33 & & \\
\hline & \multirow[t]{2}{*}{$\mathrm{N}^{\prime}-\mathrm{Sn}-\mathrm{Pog}$ angle } & M & 166.26 & 5.40 & \multirow{2}{*}{1.89} & \multirow{2}{*}{.069} \\
\hline & & $\mathrm{F}$ & 162.60 & 5.20 & & \\
\hline & \multirow[t]{2}{*}{$\mathrm{N}^{\prime}-\mathrm{Pr}-\mathrm{Pog}$ angle } & M & 131.30 & 4.00 & \multirow{2}{*}{2.04} & \multirow{2}{*}{.051} \\
\hline & & $\mathrm{F}$ & 128.36 & 3.86 & & \\
\hline & & M & 91.30 & 3.74 & \multirow{2}{*}{.28} & \multirow{2}{*}{.776} \\
\hline & $\mathrm{N}^{\prime}-\mathrm{Pog}^{\prime}$ to $\mathrm{FH}$ angle & $\mathrm{F}$ & 90.90 & 3.87 & & \\
\hline & \multirow{2}{*}{$\mathrm{Z}$ - angle } & M & 78.90 & 5.54 & \multirow{2}{*}{1.11} & \multirow{2}{*}{.275} \\
\hline & & $\mathrm{F}$ & 76.43 & 6.55 & & \\
\hline & \multirow{2}{*}{ Nasolabial angle } & M & 99.40 & 14.69 & \multirow{2}{*}{-1.90} & \multirow{2}{*}{.067} \\
\hline & & $\mathrm{F}$ & 109.30 & 13.74 & & \\
\hline & \multirow{2}{*}{ Mentolabial angle } & M & 133.40 & 11.18 & \multirow{2}{*}{-1.45} & \multirow{2}{*}{.156} \\
\hline & & $\mathrm{F}$ & 139.20 & 10.60 & & \\
\hline \multirow{6}{*}{$\stackrel{\Xi}{\stackrel{\Xi}{\Xi}}$} & \multirow{2}{*}{$\mathrm{Sn}-\mathrm{St}$} & $\mathrm{M}$ & 21.23 & 3.33 & \multirow{2}{*}{.37} & \multirow{2}{*}{.714} \\
\hline & & $\mathrm{F}$ & 20.86 & 1.89 & & \\
\hline & \multirow{2}{*}{ St-Me' } & M & 53.20 & 3.26 & \multirow{2}{*}{3.41} & \multirow{2}{*}{$.002 *$} \\
\hline & & $\mathrm{F}$ & 48.63 & 4.02 & & \\
\hline & \multirow{2}{*}{ Nasal depth } & M & 28.73 & 4.95 & \multirow{2}{*}{.82} & \multirow{2}{*}{.419} \\
\hline & & $\mathrm{F}$ & 27.40 & 3.88 & & \\
\hline
\end{tabular}

$\overline{\text { Angular variables are measured in degree, linear variables are measured in mm. SD: standard }}$ deviation. Sig: significance, ${ }^{*}$ significant at $p \leq 0.05$. 
3. Comparison between adolescent and adult males: As illustrated in Table (3), means of the following variables $(\mathrm{N}-\mathrm{A}-$ Pog) angle, (N'-Sn-Pog') angle, Z- angle, lower lip length and nasal depth were significantly higher in adult males than those in the adolescent males. While the other variables were statistically not significant.

Table (3): Comparisons of group means between adolescent and adult males.

\begin{tabular}{ccccc}
\hline Variables & $\begin{array}{c}\text { Adolescent } \\
\text { males }\end{array}$ & $\begin{array}{c}\text { Adult } \\
\text { males }\end{array}$ & t- value & Sig. \\
\hline N-A-Pog angle & 174.53 & 178.70 & -2.61 & $.016^{*}$ \\
N'-Sn-Pog' angle & 161.90 & 166.26 & -2.80 & $.011^{*}$ \\
N'-Pr-Pog' angle & 131.83 & 131.30 & .39 & .699 \\
N'-Pog' to FH angle & 89.06 & 91.30 & -1.59 & .122 \\
Z- angle & 72.40 & 78.90 & -3.50 & $.002^{*}$ \\
Nasolabial angle & 107.40 & 99.40 & 1.94 & .067 \\
Mentolabial angle & 129.90 & 133.40 & -.84 & .408 \\
Sn-St (mm) & 20.60 & 21.23 & -.59 & .555 \\
St-Me' (mm) & 44.83 & 53.20 & -7.58 & $.000^{*}$ \\
Nasal depth (mm) & 22.90 & 28.73 & -2.87 & $.008^{*}$ \\
\hline
\end{tabular}

* significant at $\mathrm{P} \leq 0.05$.

4. Comparison between adolescent and adult females:

Adult females having higher mean values for (N'-Sn-Pog') angle, (N'-Pog' to $\mathrm{FH})$ angle, nasolabial angle, mentolabial angle, and Z- angle but statistically not significant. Meanwhile lower lip length and nasal depth showed statistically significant difference between the two age groups with the adult females having the higher values as demonstrated in Table (4).

Table (4): Comparisons of group means between adolescent and adult females.

\begin{tabular}{ccccc}
\hline Variables & $\begin{array}{c}\text { Adolescent } \\
\text { females }\end{array}$ & $\begin{array}{c}\text { Adult fe- } \\
\text { males }\end{array}$ & t- value & Sig. \\
\hline N-A-Pog angle & 175.86 & 175.13 & .38 & .707 \\
N'-Sn-Pog' angle & 162.46 & 162.60 & -.06 & .950 \\
N'-Pr-Pog' angle & 130.93 & 128.36 & 1.70 & .099 \\
N'-Pog' to FH angle & 88.63 & 90.90 & -1.84 & .075 \\
Z- angle & 74.00 & 76.43 & -1.13 & .265 \\
Nasolabial angle & 106.53 & 109.30 & -.66 & .514 \\
Mentolabial angle & 134.63 & 139.20 & -1.35 & .186 \\
Sn-St (mm) & 20.90 & 20.86 & .04 & .963 \\
St-Me' (mm) & 45.76 & 48.63 & -2.15 & $.040^{*}$ \\
Nasal depth $(\mathrm{mm})$ & 24.00 & 27.40 & -2.29 & $.030^{*}$ \\
\hline *=significant at $\mathrm{P} \leq 0.05$ & & & &
\end{tabular}

\section{DISCUSSION}

Previous investigations ${ }^{(17,18)}$ have shown that total facial convexity increases with age. This is equated by the angle $\mathrm{N}^{\prime}-$ Pr-Pog' that decreases with age. This increase in total facial convexity has been shown to be due primarily to a greater increase in the nasal prominence relative to the rest of the soft tissue profile with growth. All males and females in this study demonstrated an increase in total facial convexity with age which comes in agreement with these studies.

Angles of convexity of the facial skeleton and soft tissue excluding the nose tended to be larger in the adult males, indicating relatively straighter facial profile in adult males.This indicates that the skeletal prognathism and soft tissue prognathism of the chin are closely related, rapid increase in skeletal prognathism would serve to bring the soft tissue chin 
forword making the soft tissue profile less convex. But, no significant differences between males and females trend with respect to facial convexity were noted. This comes in agreement with the result obtained by Zylinski et al., ${ }^{(21)}$ and Bishara et al., (22).

Merrifield ${ }^{(23)}$ found that, in the 11 to 15 years age group, the average $Z_{-}$- angle was $78^{\circ} \pm 5^{\circ}$ with females demonstrating higher values than males. In adult, he found the average $\mathrm{Z}-$ angle to be $80^{\circ} \pm 5$ with males exhibiting higher values than females. The finding of this study comes in agreement with Merrifield's study.

The upper lip length tends to increase in length as a result of growth until approximately age 14 years and that, after full eruption of the maxillary central incisors, a constant vertical relation ship was maintained to the edge of the incisors. Nanda et al., ${ }^{(12)}$ reported similar finding with the vertical growth of the upper lip being completed by 15 years for both boys and girls. Graber ${ }^{(24)}$ found that the lower lip demonstrated continued growth past age 15 years for girls and through age 18 years for boys. Similar finding also is seen in this study.

Small changes in the upper lip length for males indicate a probability that those with a short lip at 10 years will continue to have a short upper lip even at age 18 years. The impact of this finding on treatment planning is significant because the excessive display of upper gingiva, if present, should be corrected early to establish a more favorable tooth / lip relation ship.

In males, the nasolabial angle decreases with age. This comes in agreement with the result of Abdul-Qadir ${ }^{25}$. It is difficult to identify the exact cause for the reduction in the nasolabial angle since this angle is formed by two lines, one from the nose and the other from the upper lip and both independent of each other, the measurement of this angle alone does not reveal which component is responsible for the variability. It could be the nose, the lip or both. In females, this angle increased with age which comes in contrast with the finding obtained by Geneccove et al., ${ }^{(25)}$.

The mentolabial angle depends on the lower incisor inclinations and the chin position. Since the females having a more convex facial profile during adolescence and adulthood, indicating a more retruded chin, this may explain the larger mentolabial angle in females than in males in this study.

Nasal depth increases from adolescent to adulthood. This come in agreement with Nanda et al., ${ }^{(12)}$, they showed that from the age 7 to 16 the median growth curves for males and females run parallel to each other, the size of the nasal depth is approximately similar but the curve being to diverge from age 16 to 18 , the male group showed growth acceleration to the females group.

\section{CONCLUSIONS}

With increasing age (growth), the adult males were having a relatively straighter facial profile and this fact is represented by greater angles of convexity of facial skeleton, soft tissue excluding the nose and $\mathrm{Z}$ - angle. During adulthood, for both gender, a significant increase in nasal depth and lower lip length were noticed.

\section{REFERENCES}

1. Nanda RS. The contributions of craniofacial growth to clinical orthodontics. Am J Orthod Dentofacial Orthop. 2000; 117(5): 353-555.

2. Hwang H, Kim W, McNamara J. Ethnic differences in the soft tissue profile of Korean and European-American adult with normal occlusions and well balance faces. Angle Orthod. 2002; 72(1): 72-80.

3. Ochoa BK, Nanda RS. Comparison of maxillary and mandibular growth. Am J Orthod Dentofacial Orthop. 2004; 125(2): 148-159.

4. Tadic N, Woods MG. Incisal and soft tissue effects of maxillary premolar extraction in class II treatment. Angle Orthodt. 2006; 77(5): 808-816.

5. Erbay EF, Caniklioglu CM, Erbay SK. Soft tissue profile in Anatolian Turkish adults: Part I. evaluation of horizantal lip position using different soft tissue analysis. Am J Orthod Dentofacial Orthop. 2002; 121: 57-64.

6. Basciftci FA, Uysal T, Buyukerkmen A. Determination of Holdaway soft tissue norms in Anatolian Turkish adults. Am J 
Orthod Dentofacial Orthop. 2003; 123(4): 395-400.

7. Arnett CW, Jelic JS, Kim J, Gumming DR, Beress A, Worley CM, Chung B, Bergman R. Soft tissue cephalometric analysis: diagnosis and treatment planning of dentofacial deformity. Am J Orthod Dentofacial Orthop. 1999; 116: 239-253.

8. Yang H, Nahm D, Baek S. Which hard and soft tissue factors relate with the amount of buccal corridor space during smiling? Angle Orthod. 2007; 78(1): 511.

9. Sforza C, Laino A, D'Alessio R, Dellavia C, Grandi G, Ferrario VF. Three dimensional facial morphometry of attractive children and normal children in the deciduous and early mixed dentition. Angle Orthod. 2007; 77: 1025-1033.

10. Blanchette ME, Nanda RS, Gurrier F, Ghosh J, Nanda SK. A longitudinal cephalometric study of the soft tissue profile of short and long face syndrome from 7 to 17 years. Am J Orthod Dentofacial Orthop. 1996; 109(2): 116-131.

11. Meng H, Goorhuis J, Kapila S, Nanda $S$. Growth changes in the nasal profile from 7 to 18 year of age. Am J Orthod Dentofacial Orthop. 1988; 94: 317-326.

12. Nanda R, Meng H, Kapila S, Goorhuis J. Growth changes in the soft tissue facial profile. Angle Orthod. 1990; 60(3): 177-190.

13. Nute SJ, Moss JP. Three dimensional facial growth studied by optic surface scanning. J Orthod. 2000; 27(1): 31-38.

14. Akgul AA, Toygar TU. Natural craniofacial changes in the third decade of life. Am J Orthod Dentofacial Orthop. 2002; 122(5):512-522.

15. Saglam AMS, Gazilerli U. Analysis of
Holdaway soft tissue measurements in children between 9 and 12 years of age. Eur J Orthod. 2001; 23: 287-294.

16. Thurow RC. Atlas of orthodontic principles. St. louis. CV Mosby. 1970; Pp: 30-89.

17. Chaconas SJ, Bartroff JD. Prediction of normal soft tissue changes. Angle Orthod. 1975; 45: 12-25.

18. Subtelny JD. A longitudinal study of soft tissue facial structures and their profile characterstics defined in relation to underlying skeletal structure. Am J Orthod. 1959; 45: 481-507.

19. Neger M. A quantitative method for the evaluation of soft tissue profile. Am J Orthod. 1959; 45: 738-751.

20. Hwang HS, Kim WS, McNamara JA. A comparative study of two method of quantifying the soft tissue profile. Angle Orthod. 2000; 70 (3): 200-207.

21. Zylinski CG, Nanda RS, Kapila S. Analysis of soft tissue facial profile in white males. Am J Orthod Dentofacial Orthop. 1992; 101: 514-522.

22.Bishara SE, Jakobsen JR, Hession TJ, treder JE. Soft tissue profile changes from 5 to 45 years of age. Am J Orthod Dentofacial Orthop. 1998; 114: 698706.

23. Merrifield LL. The profile line as aid in critically evaluating facial esthetic. Am J Orthod. 1966; 52: 804-822.

24. Graber TM. Orthodontics: current principles and techniques. $3^{\text {rd }}$ ed. Mosby Inc. 2000; P: 32.

25.Abdul-Qadir MY. Comparison of craniofacial parameters and soft tissue relations among four age groups children in Mosul city (a cross-sectional study). MSc. thesis. College of Dentistry. University of Mosul. 2005. 